\title{
Biomarkers as pollution indicators with special reference to cetaceans ${ }^{1}$
}

\author{
David B. Peakall
}

Monitoring and Assessment Research Centre, King's College (London), The Old Coach House, Campden Hill, London W8 7AD, UK.

Contact e-mail: 100734.25@compuserve.com

\begin{abstract}
The limited information available on biomarkers in cetaceans and pinnipeds is reviewed. The main problems with their application to cetaceans are the difficulties in obtaining suitable tissue material and in carrying out experimental work to relate pollutant levels and effects. A white whale population from the Gulf of St Lawrence has been found to have a high incidence of tumours and the presence of adducts was related to exposure to benzo(a)pyrene (PAH), a well known carcinogen. Some research has been carried out on induction of Mixed Function Oxidases (MFOs) (mainly cytochrome P450 system) in cetaceans, but the results are not yet conclusive. Studies on other groups of animals suggest that MFOs may be valuable biomarkers, particularly if techniques to measure them in biopsy skin samples are further developed. The goal should be that wild cetaceans are physiologically normal, biomarkers can be used to identify populations whose physiological functions are outside normal limits because of excessive exposure to pollutants. Since no pristine environments currently exist, measurements of biomarkers along gradients of pollutant exposure are needed to establish physiological nornality in cetaceans.

KEYWORDS: BIOMARKERS; DNA ADDUCTS; HAZARD ASSESSMENT; IMMUNOSUPPRESSION; PHYSIOLOGY; POLLUTION-HAHS; POLLUTION- ORGANOCHLORINES; POLLUTION-PESTICIDES; WHITE WHALE; STRIPED DOLPHIN; FIN WHALE; MINKE WHALE; SHORT-FINNED PILOT WHALE; DALL'S PORPOISE; PINNIPEDS
\end{abstract}

\section{INTRODUCTION}

At a recent symposium organised by the European Science Foundation (Peakall and Walker, 1994) biomarkers were defined as:

'A biological response to a chemical or chemicals that gives a measure of exposure and, sometimes. also of toxic effect'.

The term 'biological response' is usually taken to be any response (biochemical, physiological, pathological or behavioural) up to the organisational level of the intact animal. Biological responses at higher organisational levels, such as population or community structure, are usually termed 'bio-indicators'.

Biomarkers are often divided into 'biomarkers of exposure' and 'biomarkers of effect', but this is misleading. All biomarkers indicate exposure and demonstrate an effect of some sort or another; if an additional term is thought necessary it should be 'biomarkers of toxic or adverse effect'.

I This paper was originally submitted to the IWC Scientific Committee as SC/M95/P8. 
The main reason for using biomarkers is to overcome the difficulty in conventional toxicology of making a hazard assessment under field conditions. The basic approach of conventional toxicology is to measure the amount of the chemical present and then relate that, via animal experiments (or correlation to observed adverse effects), to adverse effects caused by the chemical. While we have a large amount of data on the levels of pollutants in marine mammals, we have comparatively little information on the effects that these pollutants have on them (Reijnders et al., 1999).

\section{BIOMARKERS: DIFFICULTIES WITH MARINE MAMMALS}

Although biomarkers are becoming widely used in environmental assessment there are two specific difficulties in the use of them to study marine mammals and, more specifically, cetaceans.

\section{(1) Collection of samples}

There have been strenuous efforts to conserve cetaceans and thus, more than for almost any other group of animals, the taking of animals for scientific study is controversial (e.g. Donovan, 1992). Therefore, samples must either be obtained non-destructively or obtained from animals that have already died.

\section{(2) Practical difficulties with experimental studies}

No experimental studies on the effects of pollutants on cetaceans have been carried out to date and thus we have to depend on either correlations between effects seen and pollutant levels without being able to confirm a cause-and-effect relationship, or on extrapolation from other groups of animals. In the context of the latter approach, the experimental data available on pinnipeds will be briefly reviewed below. Another potential approach, already used on a number of species, but as yet rarely on cetaceans (see Busbee et al., 1999), is the use of tissue culture for experiments.

\section{BIOMARKER DATA AVAILABLE IN CETACEANS}

\section{DNA adducts}

Although the covalent binding of environmental pollutants to DNA (adduct formation) is a clear demonstration of exposure to these agents, it is merely an indication of possible adverse effects. Any alteration to genetic material must be taken seriously but it should be remembered that a range of repair mechanisms exist.

The group of compounds that have been studied in the most detail for adduct formation are the polynuclear aromatic hydrocarbons $(\mathrm{PAHs})$; some, such as benzo(a)pyrene $(\mathrm{BaP})$, are known carcinogens. There are a considerable number of techniques available for analysing their adduct formation (see Shugart, 1993) that can be broadly allocated to two categories, those that measure the total number of adducts and those that identify specific adducts.

BaP-DNA adducts were found in the brain tissue of three white whales (Delphinapterus leucas) found dead in the St Lawrence (Martineau et al., 1988). In a later study, ten out of eleven white whales examined had these adducts in the brain and they were also present in the six livers examined (Martineau et al., 1994). By contrast, no such adducts were found in the brains of four white whales killed by native hunters in the Mackenzie Delta region of the 
Arctic (Martineau et al., 1994). The finding of BaP-adducts in the brains of the St Lawrence white whales can be correlated to the high incidence (19\%) of tumours found in whales that underwent post-mortems (Martineau et al.. 1999).

In contrast, studies by Ray et al. (1991) found no differences in the total number of adducts in the livers of eight white whales from Hudson Bay, six from the Mackenzie Delta or four from the St Lawrence.

More extensive studies, preferably measuring both total PAH adducts and BaP-adducts, are needed. Since DNA adducts can be measured in skin samples (L. Shugart, pers. comm.) it should be possible to obtain these samples non-destructively from free-ranging cetaceans using biopsy techniques (Aguilar and Borrell, 1994). However, it will be necessary to establish relationships between the levels of adducts in the skin and in target organs using material that is available for autopsy.

\section{Mixed Function Oxidase induction}

The Mixed Function Oxidases (MFOs) or mono-oxygenases are a group of enzymes that are capable of being induced by a wide range of substances, both natural and man-made. They form an important defence mechanism, which initially evolved to enable animals to deal with plant or animal toxins in their diet by increasing the rate of metabolism of these toxins. In the modern world, the same system is often called into play by man-made chemicals, such as organochlorines.

A study based on skin biopsy samples from seven striped dolphins (Stenella coeruleoalba) and nine fin whales (Balaenoptera physalus) from the Mediterranean Sea has been reported by Fossi et al. (1992). The MFO activity in the striped dolphins was four times higher than in the fin whales and this was ascribed to the higher levels of PCBs and total DDT in the dolphins; however, this variation is well within the inter-species variation that has been reported, even between fairly closely related species (Walker, 1980). The important point of this rather preliminary study is that MFO activity in the skin, although much lower than the activity in the liver (Watanabe et al., 1989), can be readily measured.

The characteristics of the cytochrome P450 system of the minke whale (Balaenoptera acutorostrata) have been studied (Goksøyr et al., 1985; 1986). Studies on three additional species of cetaceans have been reported by Watanabe et al. (1989). While this is valuable baseline information it does not provide pollutant related information. The capacity of the MFO systems of cetaceans to be induced and thus aid in the metabolism and excretion of organochlorine compounds has been reviewed by Tanabe and Tatsukawa (1992). They concluded that 'these animals have a low capacity for degradation of these contaminants resulting from a specific mode of cytochrome $\mathrm{P} 450$ drug-metabolising enzyme systems'.

One of the clearest indications that induction of the MFO system is occurring comes from the correlation of the activity of one of the MFO enzyme (7-ethoxyresoresufin O-deethylase) with the total PCB concentration in the livers of short-finned pilot whales, Globicephala macrorhynchus (Watanabe, cited in Tanabe and Tatsukawa, 1992). In addition, strong correlations of cytochrome CYPlA with the level of toxic PCB congeners have been reported by White et al. (1994) for the white whale.

\section{Plasma hormone levels}

There have been few published studies relating hormone levels to pollutant levels in blood samples. Subramanian et al. (1987) examined the correlations of hormone levels with the levels of PCBs and DDE in the blood of the Dall's porpoise (Phocoenoides dalli). A modest negative correlation between the level of testosterone and DDE was determined but no relationship was found between testosterone and total PCBs, or aldosterone levels with either pollutant. 


\section{Immunological studies}

Despite the importance of the immune system in the link between pollutants and disease, no detailed pollutant-related immunological studies on cetaceans have been reported. However, a number of immunological studies on cetacean plasma are underway that will provide useful reference material and which could be adapted to such work (e.g. Abbott, 1979; Bossart, 1984; Brown et al., 1988; St Aubin et al., 1990; Kennedy et al., 1991; Domingo et al., 1992; Kumar and Cowan, 1994; De Guise et al., 1996; Erickson et al., 1995; Lahvis et al., 1995).

\section{EXPERIMENTAL STUDIES WITH PINNIPEDS}

In the absence of significant experimental studies on the effects of pollutants on cetaceans it is worthwhile briefly reviewing the data that are available on seals. Although both pinnipeds and cetaceans are marine mammals it should be pointed out that these two groups are not phylogenetically closely related and furthermore are known to differ in at least some responses to contaminant exposure, e.g. MFO-induction (Tanabe and Tatsukawa, 1992; Reijnders, 1994).

Studies have been carried out by Reijnders and co-workers on harbour seals (Phoca vitulina) which were fed fish from highly polluted areas such as the Baltic or Wadden Seas, the control group being fed fish from the relatively clean North Atlantic. In the first study (Reijnders, 1986) a significant decrease in reproductive success was found in the group fed with the fish from polluted areas. However, no differences were found in the levels of circulating hormones. Studies were also carried out on the levels of vitamin A and thyroid hormone levels (Brouwer et al., 1989). Significantly lower levels of plasma retinol, total and free thyroxine and triiodothyronin were found in those seals on the contaminated diet. In a subsequent experiment a variety of immunological tests were carried out and it was found that there was functional impairment of both the innate and adaptive immune systems in the seals fed on herring from the Baltic (De Swart et al., 1994; Ross et al., 1995). Vitamin A levels were also significantly lower in this group, confirming earlier studies.

\section{HAZARD ASSESSMENT USING BIOMARKER DATA}

In hazard assessment using biomarker data, it is necessary to define what 'no hazard' is. Peakall (1992) argued that a reasonable position is that 'the physiological functions of organisms, outside the exclusion zone, should be within normal limits'. The rationale for having an 'exclusion zone' in hazard assessment is that one cannot expect physiological normality in the immediate area of, for example, an industrial port, although in general it would not be considered acceptable to pollute an entire estuary. Fortunately, for marine mammals, the question of 'exclusion zones' can be ignored. For cetaceans, therefore, it can be argued that a reasonable standard could be that human activities do not cause their physiological function to be outside the normal limits.

Such an approach can be compared to a thorough human medical check-up where a range of tests are carried out and action is taken only if the measurements (cholesterol level, blood pressure, etc.) are outside normal limits. The advantages of the approach are twofold.

(1) It is, initially, independent of the pollutants involved and thus avoids the problem of mixtures and unknown substances. Only if abnormal function is found is it necessary to make detailed investigations.

(2) It is philosophically defensible. It recognises that pollutants will be present (analytical chemistry is too good for zero to be a practical objective) and rather stresses that the 
function of the animals living in the area should be normal. Thus it provides a realistic target for remedial action.

The major limitations of the approach are as follows.

(1) The definition of physiological normality presents two difficulties: no completely pristine environment now exists; and there are the previously mentioned practical difficulties of working with cetaceans, particularly the large whales and beaked whales. Areas of low pollution and, more specifically, measurements along gradients are needed to establish, as far as possible, physiological normality.

(2) It requires that a sufficient range of tests are available to be able to determine with confidence that physiology is indeed normal and that all major classes of pollutants have been covered.

(3) It does not address the question as to whether harm is caused by the altered physiological state. This needs further investigation in terms of costs to the individual/population involved.

The first and second limitations are, at the moment, the most serious with respect to cetacean studies. More data are needed to establish normality and more tests (e.g. non-destructive tests for immunological studies) need to be developed. The third point may be controversial but physiological normality does not seem an unreasonable goal for free-living open ocean animals.

\section{CONCLUSIONS}

At present there are few studies on cetaceans that can be directly related to the issue of biomarkers. Clearly much more work is needed. One example of the type of study that could be useful is that of the population of white whales that live in the polluted St Lawrence Estuary, Canada. The main findings of a number of years of study were a high prevalence of tumours (19\% of the 73 whales autopsied - Martineau et al., 1999) and a high incidence of lesions to the digestive system (53\% of examined animals) and mammary glands (45\% of adult females examined) (Béland et al., 1993). A prima facia case can be made for the involvement of chemicals based on the presence of BaP-DNA adducts in the brain at levels associated with carcinogenesis in laboratory animals. A healthy Arctic population of the same species had neither a high prevalence of tumours nor detectable levels of BaP-DNA adducts in the brain.

High levels of PCBs (and other organochlorines) have been recorded in these white whales and other cetaceans. But although there is evidence that the capacity of the MFO system in cetaceans is relatively low compared to other orders of mammals and that some induction of MFOs has occurred, no definite proof of harm has been generated.

Nevertheless, concerns remain in relation to this group of compounds. Firstly, there is good evidence that present levels are causing problems for pinnipeds in the Baltic and Wadden Seas (Helle et al., 1976; Reijnders, 1980). Secondly, although there are bans and restrictions on PCBs in many countries, it is likely that the release of these persistent compounds into the environment will continue for many years to come (IWC, 1997).

\section{RECOMMENDATIONS}

(1) Biomarkers (certainly DNA-adducts and MFO induction and, if possible, others) must be measured in skin samples collected along known pollution gradients and be related to the levels of pollutants measured in the same samples. Blood samples can also be used to examine biomarkers such as adduct formation with haemoglobin and enzyme activity; 
although this requires the capture of animals. It is important to measure biomarkers in healthy living animals rather than stranded specimens. Examples of gradients that could be studied include the white whale in the St Lawrence compared to those in the Arctic, and harbour porpoises in the Baltic, North Sea and open Atlantic (e.g. IWC, 1999).

(2) Measurements of biomarkers in the skin must be related to those in other organs (brain for adducts, liver for MFO induction) which are normally used. This should be carried out with animals legally taken or killed by accident rather than on stranded animals, again to ensure that physiological normality is more probable.

(3) If such information is to be accepted and used in the conservation of cetaceans these biomarker studies must be coordinated. This is needed to ensure that both measurements of biomarkers and residue levels are comparable, and that the framework of the studies is organised so that they can be used as part of the regulatory process.

Finally, it is vital to have much more information on the effects of pollutants on cetaceans. Additional collection of residue data alone is not helpful and indeed, it can be argued that analytical chemical studies should only be undertaken in support of detailed biological studies.

\section{ACKNOWLEDGEMENTS}

The author wishes to thank J. Stein, C. Walker and two anonymous reviewers for their help with this manuscript.

\section{REFERENCES}

Abbott, I.A. 1979. Some tropical species related to Antithamnion (Rhodophyta, Cermiaceae). Phycologia $18(3): 213-27$.

Aguilar, A. and Borrell, A. 1994. Assessment of organochlorine pollutants in cetaceans by means of skin and hypodermic biopsies. pp. 245-67. In: M.C. Fossi and C. Leonzio (eds.) Non-Destructive Biomarkers in Vertebrates. Lewis Publishers, Boca Raton, Florida. 457pp.

Béland, P., de Guise, S., Girard, C., Lagacé, A., Martineau, D., Michaud, R., Muir, D.C.G.. Norstrom, R.J.. Pelletier, E., Ray, S. and Shugart, L.R. 1993. Toxic compounds and health and reproductive effects in St Lawrence beluga whales. J. Gt Lakes Res. 19(4):766-75.

Bossart, G.D. 1984. Suspected acquired immunodeficiency in an Atlantic bottlenosed dolphin with chronic-active hepatitis and lobomycosis. I. Am. Vet. Med. Assoc. $185(11): 1+13-4$

Brouwer, A., Reijnders, P.J.H. and Koeman, J.H. 1989. Polychlorinated biphenyl (PCB)-contaminated fish induces vitamin $\mathrm{A}$ and thyroid hormone deficiency in the common seal (Phoca vitulina). Aquat. Toxicol. 15:99-106.

Brown, E.D., Bossart, G.D. and Reynolds, J.E.I.I.I. 1988. The microscopic and immunohistologic anatomy of the endocrine pancreas of pygmy and dwarf sperm whales (Kogiidae). Mar. Mammal Sci. 4(4):29l-6.

Busbee, D., Tizard, I., Scott, J., Ferrick, D. and Ott-Reeves. E. 1999. Environmental pollutants and marine mammal health: the potential impact of hydrocarbons and halogenated hydrocarbons on immune system dysfunction. I. Cracean Res. Manage. (special issuc) 1:223-48.

De Guise, S., Bernier, J., Defresuc, M.M., Martineau, D., Bélind, P. and Fournier, M. 1995. Inmune functions in beluga whales (D. leucas): evaluation of mitogen-induced blastic transformation of lymphocytes from peripheral blood, spleen and thymus. lat. Immmol. Immunopathol: 50(1-2): 117-26.

De Swart, R.L., Ross, P.S., Vedder, L.J., Timmerman, H.H., Heisterkamp, S.H., Van Loveren, H., Vos. J.G., Reijnders, P.J.H. and Osterhaus, A.D.M.E. 1944. Impairment of immune function in harbour seals (Phoca vitulina) lieeding on fish from polluted waters. Ambio $23: 155-9$

Domingo, M., Visa. J., Pumarola, M., Marco, A.J.. Ferrer, L., Rabanal, R. and Kennedy, S. 1992. Pathologic and immunocytochemical studies of morbillivirus infection in striped dolphins (Stenella cocruleoalha). Vet. Pathol. 29:1-10.

Donovan, G.P. 1992. The International Whaling Commission: Given its past, does it have a future?. pp. 23-44. In: J.J. Symoens (ed.) Symposium "Whales: Biology - Threats - Conservation». Royal Academy of Overseas Sciences, Brussels, Belgium. 26lpp. 
Erickson, K.L., Dimolfettolandon, L., Wells, R.S., Reidarson, T., Stott, J.L. and Ferrick, D.A. 1995. Development of an interleukin-2 receptor expression assay and its use in evaluation of cellular immune responses in bottlenose dolphin (Tursiops truncatus). J. Wildl. Dis. 3I(2):142-9.

Fossi, M.C., Marsili, L., Leonzio, C., Notarbartolo-di-Sciara, G., Zanardelli, M. and Focardi, S. 1992. The use of non-destructive biomarkers in Mediterranean cetaceans - preliminary data on MFO activity in skin biopsy. Mar. Pollut. Bull. 24(9):459-61.

Goksøyr, A., Tarlebø, J., Solbakken, J.E. and Klungsøyr, J. 1985. Characteristics of the hepatic microsomal cytochrome P-450 system of the minke whale (Balaenoptera acutorostrata). Mar. Environ. Res. 17:113-6.

Goksøyr, A., Solbakken, J.E., Tarlebø, J. and Klungsøyr, J. 1986. Initial characterization of the hepatic microsomal cytochrome P-450 - system of the piked whale (minke) Balaenoptera acutorostrata. Mar. Environ. Res. 19:185-203.

Helle, E., Olsson, M. and Jensen, S. 1976. PCB levels correlated with pathological changes in seal uteri. Ambio 5(5-6):261-3.

Kennedy, S., Smyth, J.A., Cush, P.F., McAliskey, M., McCullough, S.J. and Rima, B.K. 1991. Histopathology and immunocytochemical studies of distemper in harbor porpoises. Vet. Pathol. 28(1):1-7.

Kumar. D. and Cowan. D.F. 1994. Cross-reactivity of antibodies to human antigens with tissues of the bottlenose dolphin, Tursiops truncatus, using immunoperoxidase techniques. Mar. Mammal Sci. IO(2): 188-94

Lahvis, G.P., Wells, R.S., Kuehl, D.W., Stewart, J.L., Rhinehart, H.L. and Via, C.S. 1995. Decreased lymphocyte responses in free-ranging bottlenose dolphins (Tursiops truncatus) are associated with increased concentrations of PCBs and DDT in peripheral blood. Environ. Health Perspect. 103:67-72.

Martineau, D., Lagacé, A.. Béland, P., Higgins, R., Amnstrong, D. and Shugart, L.R. 1988. Pathology of stranded beluga whales (Delphinapterus leucas) from St Lawrence estuary (Québec, Canada). J. Comp. Pathol. 38:287-311.

Martineau, D., De Guise, S., Fournier, M., Shugart, L., Girard, C., Lagacé, A. and Béland, P. 1994. Pathology and toxicology of beluga whales from the St Lawrence estuary, Quebec, Canada - past, present and future. Sci. Total Environ. 154(2-3):201-15.

Martineau, D., Lair, D., De Guise, S., Lipscomb, T.P. and Béland, P. 1999. Cancer in beluga whales from the St Lawrence estuary, Quebec, Canada: a potential biomarker for environmental contamination. J. Cetacean Res. Manage. (special issue) 1:249-65.

Peakall, D.B. 1992. Animal Biomarkers as Pollution Indicators. Chapman and Hall, London. $291 \mathrm{pp}$.

Peakall, D.B. and Walker, C.H. 1994. The role of biomarkers in environmental assessment. Ecotoxicol. Environ. Saf. 3:173-9.

Ray, S., Dunn, B.P., Payne, J.F., Fancey, L., Helbig, R. and Béland, P. 1991. Aromatic DNA-carcinogen adducts in beluga whales from the Canadian Arctic and Gulf of St. Lawrence. Mar. Pollut. Bull. 22(8):392-6.

Reijnders, P.J.H. 1980. Organochlorine and heavy metal residues in harbour seals from the Wadden Sea and their possible effect on reproduction. Neth. J. Sea Res. 14:30-65.

Reijnders, P.J.H. 1986. Reproductive failure in common seals feeding on fish from polluted coastal waters. Nature, Lond. 324:456-7.

Reijnders, P.J.H. 1994. Toxicokinetics of chlorobiphenyls and associated physiological responses in marine mammals, with particular reference to their potential for ecotoxicological risk assessment. Sci. Total Environ. 154(2-3):229-36.

Reijnders, P.J.H., Donovan, G.P., Aguilar, A. and Bjørge, A. (eds.) 1999. Report of the Workshop on Chemical Pollution and Cetaceans. March 1995, Bergen, Norway. J. Cefacean Res. Manage. (special issue) $1: 1-42$.

Ross, P.S., De Swart, R.L., Reijnders, P.J.H., Loveren, H.V., Vos, J.G. and Osterhaus, A.D.M.E. 1995. Contaminant related suppression of delayed-type hypersensitivity and antibody responses in harbour seals fed herring from the Baltic Sea. Environ. Health Perspect. 103(2):162-7.

St Aubin, D.J., Geraci, J.R. and Shewen, P.E. 1990. Assessment of immunological function in captive beluga whales, Delphinapterus leucas: humoral response to sheep red blood cell antigens. pp. 159-64. In: T.G. Smith, D.J. St Aubin and J.R. Geraci (eds.) Canadian Bulletin of Fisheries and Aquatic Sciences. 224. Advances in Research on the Beluga Whale, Delphinapterus leucas. Department of Fisheries and Oceans, Ottawa.

Shugart, L. 1993. Genotoxic responses in blood. pp. 131-45. In: C.M. Fossi and C. Leonzio (eds.) Non-Destructive Biomarkers in Vertebrates. Lewis Publishers, Boca Raton, Florida. 457pp.

Subramanian, A.N., Tanabe, S., Tatsukawa, R., Saito, S. and Miyazaki, N. 1987. Reduction in the testosterone levels by PCBs and DDE in Dall's porpoises of the northwestern North Pacific. Mar. Pollut. Bull. 18(12):643-6. 
Tanabe, S. and Tatsukawa, R. 1992. Chemical modernization and vulnerability of cetaceans: increasing toxic threat of organochlorine contaminants. pp. 161-79. In: C.H. Walker and D.R. Livingstone (eds.) Persistant Pollutants in Marine Mammals. SETAC Special Publications Series. Ist. Edn. Pergamon Press, Oxford, New York, Seoul, Tokyo.

Walker, C.H. 1980. Species variations in some hepatic microsomal enzymes that metabolize xenobiotics. Progr. Drug Metabol. 5:113-64.

Watanabe, S., Shimada, T., Nakamura, S., Nishiyama, N., Yamashita, N., Tanabe, S. and Tatsukawa, R. 1989. Specific profiles of liver microsomal cytochrome P-450 in dolphin and whales. Mar. Environ. Res. 27:51-65.

White, R.D., Hahn, M.E., Lockhart, L.L. and Stegeman, J.J. 1994. Catalytic and immunochemical characterisation of hepatic microsomal cytochromes $\mathrm{P} 450$ in beluga whale (Delphinapterus leucas). Toxicol. Appl. Pharmacol. 126:45-57. 